\title{
Occurrence of pulmonary embolism related to COVID-19
}

\author{
Marie Hauguel-Moreau ${ }^{1,2,11,12}$ (I) Mostafa El Hajjam ${ }^{3,4} \cdot$ Quentin De Baynast $^{1} \cdot$ Antoine Vieillard-Baron $^{2,5}$. \\ Anne-Sophie Lot $^{6} \cdot$ Thierry Chinet $^{7,8} \cdot$ Hazrije Mustafic ${ }^{1,2}$. Céline Bégué ${ }^{1} \cdot$ Robert Yves Carlier $^{3,4}$. Guillaume Geri ${ }^{2,5}$. \\ Olivier Dubourg $^{1,2} \cdot$ Sébastien Beaune ${ }^{9,10} \cdot$ Nicolas Mansencal $^{1,2}$
}

Accepted: 24 September 2020 / Published online: 6 October 2020

(c) Springer Science+Business Media, LLC, part of Springer Nature 2020

\begin{abstract}
Recent reports have suggested an increased risk of pulmonary embolism (PE) related to COVID-19. The aim of this cohort study is to compare the incidence of PE during a 3-year period and to assess the characteristics of PE in COVID-19. We studied consecutive patients presenting with PE (January 2017-April 2020). Clinical presentation, computed tomography (CT) and biological markers were systematically assessed. We recorded the global number of hospitalizations during the COVID-19 pandemic and during the same period in 2018-2019. We included 347 patients: 326 without COVID-19 and 21 with COVID-19. Patients with COVID-19 experienced more likely dyspnea $(\mathrm{p}=0.04)$, had lower arterial oxygen saturation $(\mathrm{p}<0.001)$, higher $\mathrm{C}$-reactive protein and white blood cell (WBC) count $(\mathrm{p}<0.0001$ and $\mathrm{p}=0.001$, respectively), and a significantly higher in-hospital mortality ( $14 \%$ versus $3.4 \%, \mathrm{p}=0.04)$. Among COVID-19 patients, diagnosis of PE was performed at admission in 38\% $(n=8)$. COVID-19 patients with diagnosis of PE during hospitalization $(n=13)$ had significantly more dyspnea $(\mathrm{p}=0.04)$, lower arterial oxygen saturation $(\mathrm{p}=0.01)$, less proximal $\mathrm{PE}(\mathrm{p}=0.02)$, and higher heart rate $(\mathrm{p}=0.009)$, CT severity score $(\mathrm{p}=0.001), \mathrm{C}$-reactive protein $(\mathrm{p}=0.006)$ and WBC count $(\mathrm{p}=0.04)$. During the COVID-19 outbreak, a 97.4\% increase of PE incidence was observed as compared to 2017-2019 and the proportion of hospitalizations related to PE was $3.7 \%$ versus $1.3 \%$ in $2018-2019$ ( $\mathrm{p}<0.0001$ ). In conclusion, the COVID-19 pandemic leads to a dramatic increased incidence of PE. Physicians should be aware that PE may be diagnosed at admission, but also after several days of hospitalization, with a different clinical, CT and biological features of thrombotic disease.
\end{abstract}

Keywords COVID-19 $\cdot$ Pulmonary embolism $\cdot$ Thrombosis

Electronic supplementary material The online version of this article (https://doi.org/10.1007/s11239-020-02292-4) contains supplementary material, which is available to authorized users.

Marie Hauguel-Moreau

marie.hauguel@aphp.fr

1 Department of Cardiology, Ambroise Paré Hospital, Assistance Publique-Hôpitaux de Paris (AP-HP), Centre de référence des cardiomyopathies et des troubles du rythme cardiaque héréditaires ou rares, Université de VersaillesSaint Quentin (UVSQ), Boulogne-Billancourt, France

2 INSERM U-1018, CESP, Epidémiologie clinique, UVSQ, Université de Paris Saclay, Villejuif, France

3 Department of Radiology, Ambroise Paré Hospital, AP-HP, UVSQ, Boulogne-Billancourt, France

4 INSERM U 1179, Handicap Neuromusculaire, UVSQ Paris-Saclay, Garches, France

5 Intensive Care Unit, Ambroise Paré Hospital, AP-HP, UVSQ, Boulogne-Billancourt, France
6 Department of medical information, Ambroise Paré Hospital, APHP, Boulogne-Billancourt, France

7 Department of Respiratory Diseases and Thoracic Oncology, Ambroise Paré Hospital, APHP, UVSQ, Boulogne-Billancourt, France

8 EA 4340 BECCOH, UVSQ, Université Paris Saclay, 92100 Boulogne-Billancourt, France

9 Department of Emergency Medicine, Ambroise Paré Hospital, AP-HP, UVSQ, Boulogne-Billancourt, France

10 FHU SEPSIS IFrancenserm UMR 1144, Université Paris Centre, Paris, France

11 AP-HP, Hôpital Universitaire Ambroise Paré, Service de Cardiologie et des Maladies Vasculaires, 9 avenue Charles de Gaulle, 92100 Boulogne, France

12 ACTION Study Group, Paris, France 


\section{Highlights}

- A dramatically increased in pulmonary embolism (PE) admissions were observed during COVID-19 pandemic.

- Patients with PE presented with two distinct features of thrombotic disease: patients with COVID-19 and PE diagnosis at admission, who had similar characteristics with non-COVID-19 patients, and patients with COVID19 and PE diagnosis during hospitalization, who had a significantly different presentation (higher inflammatory syndrome, more distal thrombosis process, higher SARSCoV-2 CT severity score).

- This highlights the hypothesis of a local intrapulmonary thrombosis rather than an embolism.

\section{Introduction}

All our health care systems have been recently impacted by the emergence of the acute respiratory syndrome coronavirus 2 (SARS-CoV-2) [1]. This new disease, COVID19 , exhibits various clinical presentations [2,3]. One of the concerns of COVID-19 is the increased thrombotic risk, resulting in pulmonary embolism (PE) [4-9]. However, little is known about the characteristics of patients presenting with PE and COVID-19. The aim of the study was to compare the incidence of PE during a 3-year period (including COVID-19 outbreak) and to assess the characteristics of PE in COVID-19.

\section{Methods}

Between March 2nd and April 30th 2020, all patients referred for pulmonary computed tomography (CT) in our university hospital with a PE diagnosis were prospectively included. There was no exclusion criterion. A search for COVID-19 was systematically performed, using a polymerase-chain-reaction (PCR) and/or typical CT pattern of SARS-CoV-2 [10, 11]. Treatment and management was left to physicians'discretion, according to current guidelines [10]. A historical cohort of PE included all consecutive patients referred for PE at our university hospital between January 1st, 2017 and March 1st, 2020. We identified patients presenting with PE using the International Classification of Diseases version 10 until the COVID-19 outbreak (I260 and I269 codes). We systematically reviewed all clinical parameters, electrocardiogram (ECG), computed tomography (CT), echocardiography and biomarkers. We compared the characteristics of PE in patients presenting with COVID-19 with the characteristics of PE diagnosed between 2017 and 2020 in patients without COVID-19. The study was approved by the Institutional Data Protection Authority of Paris Saclay University Hospitals.

Diagnosis of PE was performed by pulmonary CT angiography, using a 256 slice multi-detector CT (GE Healthcare Revolution, Milwaukee, WI). Multi-detector chest CT angiography was performed after intravenous injection of $50 \mathrm{ml}$ iodinated contrast agent (Iomeron $400 \mathrm{mg} \mathrm{I} / \mathrm{mL}$, Bracco Imaging, Milan, Italy) at a flow rate of $3.5 \mathrm{~mL} / \mathrm{s}$, with a trigger positioned on the main pulmonary artery. CT parameters were $120 \mathrm{kVp}$, average tube current $300 \mathrm{~mA}$, $80 \times 0.625 \mathrm{~mm}$, rotation time $0.28 \mathrm{~s}$, pitch 0.992 and CTDI vol of $4.28 \mathrm{mGy}$. Chest CT is a cornerstone of the diagnostic work-up and follow-up for patients with COVID-19. Both features COVID-19 lung involvement and PE were prospectively analyzed on a PACS workstation (Carestream Health, Rochester, NY) by an experienced radiologist blinded to clinical and biological data. The degree of lung involvement by SARS-CoV-2 was assessed for each lobe and classified as none $(0 \%)$, minimal (1\%-25\%), mild (26\%-50\%), moderate $(51 \%-75 \%)$, or severe $(76 \%-100 \%)$. For each lobe, no involvement corresponded to a score of 0 , minimal involvement to a score of 1 , mild involvement to a score of 2 , moderate involvement to a score of 3 , and severe involvement to a score of 4 . An overall lung "total severity score" was reached by summing the five lobe scores (range of possible scores, 0-20) [11, 12].

Pulmonary embolism was diagnosed if an endoluminal thrombus was present in a normal-sized or enlarged vessel. The location of PE, i.e., the site of the largest thrombus, was noted. Assessment of right ventricular size was performed by $\mathrm{CT}$ and echocardiography. Right ventricular size was systematically assessed using a CT four-chamber view passing through the mitral and tricuspid valves. We calculated the right to left ventricular area ratio and a right ventricular dilation was defined as a right to left ventricular area ratio $>1$ [13]. Echocardiographic examinations were performed using a Vivid 9, Vivid E95 or S70 system (GE Medical Systems, Horten, Norway). In an apical four-chamber view, a right ventricular dilation was defined as a right to left ventricular area ratio $>0.6$ [10]. Clinical presentation, simplified version of pulmonary embolism severity index (sPESI) [13, 14], ECG, location of pulmonary embolism by CT, right ventricular size by $\mathrm{CT}$ and by echocardiography, troponin I, D-dimers, plasma N-terminal-pro B-natriuretic peptide concentration (proBNP) and classification of PE severity (high-risk, intermediate [-high or -low] risk and low risk PE) [10] were systematically assessed. Finally, we recorded the global number of hospitalizations during the COVID-19 pandemic and during the same period in 2018 and 2019 and the number of patients presenting with COVID-19. 
Statistical analysis was performed using StatView software version 4.5 (Abacus Concepts, Berkeley, CA). Continuous variables are presented as mean \pm SD (standard deviation) and categorical data are presented as absolute values and percentages. Continuous and categorical variables were compared using the chi-square test or Fisher's exact test and unpaired t test, respectively. Missing data were addressed by listwise deletion. A value of $p<0.05$ was considered statistically significant.

\section{Results}

We included 347 patients presenting with PE: 326 without COVID-19 and 21 patients with COVID-19. The characteristics of our population are presented in Table 1. Patients with PE and COVID-19 were significantly more likely to experience dyspnea $(p=0.04)$, presented with lower arterial oxygen saturation $(\mathrm{p}<0.001)$, higher $\mathrm{C}$-reactive protein and white blood cell (WBC) count $(\mathrm{p}<0.0001$ and $\mathrm{p}=0.001$, respectively), and a significantly higher in-hospital mortality $(\mathrm{p}=0.04)$. No patient with PE and COVID-19 had normal D-dimers, but three patients (14\%) had D-dimers lower than $2500 \mathrm{ng} / \mathrm{mL}$ (versus 121 patients [37\%] in patients with PE without COVID-19 [ $p=0.04]$ ). The prevalence of proximal PE was significantly higher in patients without COVID-19 ( $40 \%$ versus $14 \%, \mathrm{p}=0.02$ ).

Among patients with COVID-19, pulmonary embolism was diagnosed at admission in only $38 \%(\mathrm{n}=8)$ with a clinical presentation of PE. In the remaining patients with COVID-19 $(n=13)$, diagnosis of PE was performed at day $8.5 \pm 6.3$ of hospitalization, because of worsening of symptoms (acute degradation of hemodynamic or respiratory status) (Table 2). All of these patients received a prophylactic anticoagulant treatment (Supplementary Table 1). The initial diagnosis of admission was SARS-CoV-2 pneumonia without PE. In comparison with COVID-19 with a diagnosis of $\mathrm{PE}$ at admission, patients who were diagnosed PE during hospitalization had a higher rate of dyspnea $(p=0.04)$, a higher heart rate $(p=0.009)$, lower arterial oxygen saturation $(\mathrm{p}=0.01)$, higher $\mathrm{C}$-reactive protein and WBC count ( $p=0.006$ and $p=0.04$, respectively), a higher sPESI $(\mathrm{p}=0.006)$ and a higher SARS-CoV-2 severity CT score $(\mathrm{p}=0.001)$. Pulmonary embolism without proximal location (Fig. 1) was significantly more frequent in patients developing PE during hospitalization $(\mathrm{p}=0.02)$.

Clinical and biological characteristics of COVID-19 patients with $\mathrm{PE}$ at admission and non COVID-19 patients were similar, except for arterial oxygen saturation $(p=0.03)$ (Tables 1 and 2). Heart rate, C-reactive protein, WBC count were significantly higher in COVID-19 patients with PE diagnosed during hospitalization as compared to patients without COVID-19 (105 bpm versus 91 bpm, $p=0.04,157$ versus $50 \mathrm{mg} / \mathrm{L}, \mathrm{p}<0.0001,14,430$ versus $9672 \times 10 * 9 / \mathrm{L}$, $\mathrm{p}<0.001$, respectively) and arterial oxygen saturation was significantly lower $(75 \%$ versus $95 \%, \mathrm{p}<0.0001)$.

Figure 2 shows the evolution of number of patients presenting with PE between 2017 and 2020. As compared to previous years, we found a significant increase of admissions for PE during the COVID-19 pandemic (increase of $97.4 \%$ in April 2020, as compared to the mean number of PE in 20172019). During the COVID-19 pandemic period (March 2nd to April 30th, 2020), the global number of hospitalizations decreased by $40 \%: 1614$, as compared to 2683 and 2680 during the same time periods in 2018 and 2019, respectively. During this same period, 415 patients were hospitalized for COVID-19 and the prevalence of PE among COVID-19 patients was $5.1 \%$. The proportion of PE-related hospitalizations was $1.3 \%$ in 2018 and 2019 versus $3.7 \%$ during the COVID-19 pandemic $(\mathrm{p}<0.0001)$.

\section{Discussion}

The present study demonstrates an increased incidence of PE during COVID-19 pandemic. Interestingly, we found two patterns of patients presenting with PE and COVID-19 with significant differences: patients with $\mathrm{PE}$ at admission and patients with PE diagnosed during hospital stay.

Several studies have recently alerted on the frequent occurrence of venous thromboembolic disease in patients with COVID-19 [4, 9]. We found consistent results in our university hospital, with a 2.85 -fold increase of PE hospitalizations. Pulmonary embolism is a well-known thromboembolic disease. Several predisposing factors have been widely published, such as previous PE, surgery, cancer, oral contraceptive therapy and immobilization [10]. To explain the increase in PE incidence during COVID-19 outbreak, several causes have been suggested. One could be that patients suffering from COVID-19 may be bedridden. In our study, $38 \%$ of patients with COVID-19 had a diagnosis of PE at admission. Interestingly, characteristics of these patients were similar to those of PE patients without COVID-19, suggesting a same thromboembolic process, with a predisposing factor related to immobilization. On the other hand, we individualized another group of patients with PE and COVID-19: patients developing PE during hospitalization. Those patients presented several clinical, biological and radiological differences, as compared to patients with PE without COVID-19 and to patients with COVID-19 and PE diagnosis at admission: important inflammatory syndrome, more severe pulmonary pattern of COVID-19, more dyspnea, increased heart rate, lower arterial oxygen saturation and less proximal PE. This finding suggests that the delayed occurrence of PE in some patients 
Table 1 Characteristics of patients presenting with pulmonary embolism between January 1st, 2017 and April 30th, 2020

\begin{tabular}{|c|c|c|c|}
\hline & $\begin{array}{l}\text { Patients without COVID-19 } \\
\mathrm{n}=326\end{array}$ & $\begin{array}{l}\text { Patients with COVID-19 } \\
\mathrm{n}=21\end{array}$ & $\mathrm{P}$ value \\
\hline Age, years & $65.5 \pm 17.9$ & $68.2 \pm 12.9$ & 0.32 \\
\hline Male, $\mathrm{n}(\%)$ & $162(49.7 \%)$ & $13(61.9 \%)$ & 0.28 \\
\hline $\begin{array}{l}\text { Previous history of thromboembolic } \\
\text { disease, } \mathrm{n}(\%)\end{array}$ & $86(26.4 \%)$ & $2(9.5 \%)$ & 0.12 \\
\hline Recent surgery $(<3$ months $), \mathrm{n}(\%)$ & $30(9.2 \%)$ & $1(4.8 \%)$ & 0.71 \\
\hline Immobilization, $\mathrm{n}(\%)$ & $49(15.0 \%)$ & $0(0 \%)$ & 0.05 \\
\hline Chronic pulmonary disease, $\mathrm{n}(\%)$ & $19(5.8 \%)$ & $0(0 \%)$ & 0.61 \\
\hline Active neoplasia, n (\%) & $42(12.9 \%)$ & $2(9.5 \%)$ & 0.99 \\
\hline Chronic heart failure, $\mathrm{n}(\%)$ & $12(3.7 \%)^{£}$ & $0(0 \%)$ & 0.99 \\
\hline Chronic kidney disease, $\mathrm{n}(\%)$ & $20(6.1 \%)$ & $0(0 \%)$ & 0.62 \\
\hline \multicolumn{4}{|l|}{ Symptoms } \\
\hline Dyspnea, n (\%) & $225(69 \%)$ & $19(90.5 \%)$ & 0.04 \\
\hline Chest pain, n (\%) & $138(42.3 \%)$ & $6(28.6 \%)$ & 0.21 \\
\hline Syncope, n (\%) & $35(10.7 \%)$ & $1(4.8 \%)$ & 0.71 \\
\hline Shock, n (\%) & $11(3.4 \%)$ & $0(0 \%)$ & 0.99 \\
\hline Heart rate, bpm & $91 \pm 21.8$ & $96 \pm 22.5$ & 0.34 \\
\hline Systolic arterial pressure, $\mathrm{mmHg}$ & $132 \pm 23.4$ & $132 \pm 28.5$ & 0.89 \\
\hline Arterial oxyhaemoglobin saturation, $\%$ & $95 \pm 5.7$ & $80 \pm 12.2$ & $<0.0001$ \\
\hline \multicolumn{4}{|l|}{ Electrocardiogram } \\
\hline $\begin{array}{l}\text { Inversion of } \mathrm{T} \text { waves in leads V1V4, } \\
\mathrm{n}(\%)\end{array}$ & $73(22.4 \%)^{\$}$ & $7(33.3 \%)$ & 0.25 \\
\hline S1Q3T3 pattern, n (\%) & $47(14.4 \%)^{\$}$ & $1(4.8 \%)$ & 0.33 \\
\hline Right bundle branch block, n (\%) & $60(18.4 \%)^{\$}$ & $4(19.0 \%)$ & 0.99 \\
\hline \multicolumn{4}{|l|}{ Location of pulmonary embolism } \\
\hline Proximal, n (\%) & $129(40 \%)$ & $3(14 \%)$ & 0.02 \\
\hline Lobar, n (\%) & $69(21 \%)$ & $5(24 \%)$ & 0.99 \\
\hline Distal, n (\%) & $128(39 \%)$ & $13(62 \%)$ & 0.06 \\
\hline \multicolumn{4}{|l|}{ Right ventricular dilation } \\
\hline Assessed by CT, n (\%) & $98(30.0 \%)$ & $9(42.9 \%)$ & 0.22 \\
\hline Assessed by echocardiography, n (\%) & $89 / 274(32.5 \%)$ & $8(38.1 \%)$ & 0.60 \\
\hline \multicolumn{4}{|l|}{ Biological markers } \\
\hline D-dimer level, ng/mL & $4833 \pm 4644^{*}$ & $6273 \pm 3478$ & 0.20 \\
\hline Cardiac troponin $\mathrm{I}, \mu \mathrm{g} / \mathrm{L}$ & $0.45 \pm 0.32$ & $0.17 \pm 0.26$ & 0.86 \\
\hline N-terminal-proBNP, ng/L & $2134 \pm 3679^{*}$ & $1223 \pm 1722$ & 0.51 \\
\hline C-reactive protein, $\mathrm{mg} / \mathrm{L}$ & $50 \pm 62$ & $119 \pm 88$ & $<0.0001$ \\
\hline White blood cells $(\times 10 * 9 / \mathrm{L})$ & $9672 \pm 3261$ & $12,705 \pm 5405$ & 0.0001 \\
\hline sPESI & $1.2 \pm 1$ & $1.2 \pm 0.8$ & 0.99 \\
\hline \multicolumn{3}{|c|}{ Classification of pulmonary embolism severity } & 0.08 \\
\hline High risk mortality, $\mathrm{n}(\%)$ & $11(3.3 \%)$ & $0(0 \%)$ & 0.99 \\
\hline Intermediate-high risk, $\mathrm{n}(\%)$ & $71(21.8 \%)$ & $6(28.6 \%)$ & 0.53 \\
\hline Intermediate-low risk, $\mathrm{n}(\%)$ & $87(26.7 \%)$ & $10(47.6 \%)$ & 0.04 \\
\hline Low risk mortality, $\mathrm{n}(\%)$ & $157(48.2 \%)$ & $5(23.8 \%)$ & 0.03 \\
\hline In-hospital mortality, n (\%) & $11(3.4 \%)$ & $3(14 \%)$ & 0.04 \\
\hline
\end{tabular}

$C T$ Computed tomography, proBNP pro B-natriuretic peptide, $S P E S I$ simplified pulmonary embolism severity index

*Data available for 321 patients

${ }^{£}$ Data available for 324 patients

${ }^{\$}$ Data available for 325 patients 
Table 2 Characteristics of patients with COVID-19 and pulmonary embolism diagnosed at admission or during hospitalization

\begin{tabular}{|c|c|c|c|}
\hline & \multicolumn{2}{|c|}{ Patients with COVID19 } & \multirow[t]{2}{*}{$P$ value } \\
\hline & $\begin{array}{l}\text { Diagnosis of PE } \\
\text { at admission } \\
\mathrm{n}=8\end{array}$ & $\begin{array}{l}\text { Diagnosis of PE } \\
\text { during hospitalization } \\
\mathrm{n}=13\end{array}$ & \\
\hline Age, years & $69.9 \pm 15.8$ & $67.1 \pm 11.1$ & 0.29 \\
\hline Male, n (\%) & $4(50 \%)$ & $9(69 \%)$ & 0.19 \\
\hline \multicolumn{4}{|l|}{ Symptoms } \\
\hline Dyspnea, n (\%) & $5(63 \%)$ & $13(100 \%)$ & 0.04 \\
\hline Chest pain, n (\%) & $3(38 \%)$ & $3(23 \%)$ & 0.63 \\
\hline Syncope, n (\%) & $0(0 \%)$ & $1(8 \%)$ & 0.99 \\
\hline Shock, n (\%) & $0(0 \%)$ & $0(0 \%)$ & - \\
\hline Heart rate, bpm & $84 \pm 24$ & $105 \pm 17$ & 0.009 \\
\hline Systolic arterial pressure, $\mathrm{mmHg}$ & $141 \pm 24$ & $128 \pm 31$ & 0.40 \\
\hline Arterial oxyhaemoglobin saturation, $\%$ & $90 \pm 7$ & $75 \pm 10$ & 0.01 \\
\hline \multicolumn{4}{|l|}{ Location of pulmonary embolism } \\
\hline Proximal, n (\%) & $2(25 \%)$ & $1(8 \%)$ & 0.53 \\
\hline Lobar, n (\%) & $2(25 \%)$ & $3(23 \%)$ & 0.99 \\
\hline Distal, n (\%) & $4(50 \%)$ & $9(69 \%)$ & 0.19 \\
\hline \multicolumn{4}{|l|}{ Right ventricular dilation } \\
\hline Assessed by CT, n (\%) & $4(50 \%)$ & $5(38 \%)$ & 0.67 \\
\hline Assessed by echocardiography, n (\%) & $3(38 \%)$ & $5(38 \%)$ & 0.99 \\
\hline Pulmonary involvement related to COVID-19 by CT & & & 0.04 \\
\hline No involvement, $\mathrm{n}(\%)$ & $3(38 \%)$ & $1(8 \%)$ & 0.25 \\
\hline Minimal involvement, $\mathrm{n}(\%)$ & $2(25 \%)$ & $1(8 \%)$ & 0.53 \\
\hline Mild involvement, n (\%) & $2(25 \%)$ & $1(8 \%)$ & 0.53 \\
\hline Moderate involvement, n (\%) & $0(0 \%)$ & $1(8 \%)$ & 0.99 \\
\hline Severe involvement, $\mathrm{n}(\%)$ & $1(13 \%)$ & $9(69 \%)$ & 0.02 \\
\hline Total severity score & $3.5 \pm 4.7$ & $11.9 \pm 6$ & 0.001 \\
\hline \multicolumn{4}{|l|}{ Biological markers } \\
\hline D-dimer level, ng/mL & $4963 \pm 2317$ & $7148 \pm 3924$ & 0.17 \\
\hline Cardiac troponin I, microg/L & $0.27 \pm 0.39$ & $0.12 \pm 0.18$ & 0.31 \\
\hline $\mathrm{N}$-terminal-proBNP, ng/L & $1289 \pm 3521$ & $1182 \pm 1212$ & 0.92 \\
\hline C-reactive protein, $\mathrm{mg} / \mathrm{L}$ & $50 \pm 55$ & $157 \pm 81$ & 0.006 \\
\hline White blood cells $(\times 10 * 9 / \mathrm{L})$ & $9500 \pm 3310$ & $14,430 \pm 5617$ & 0.04 \\
\hline sPESI & $0.4 \pm 0.8$ & $1.6 \pm 0.5$ & 0.006 \\
\hline Classification of pulmonary embolism severity & & & 0.004 \\
\hline High risk mortality, n (\%) & $0(0 \%)$ & $0(0 \%)$ & - \\
\hline Intermediate-high risk, n (\%) & $1(13 \%)$ & $5(38 \%)$ & 0.34 \\
\hline Intermediate-low risk, $\mathrm{n}(\%)$ & $2(25 \%)$ & $8(62 \%)$ & 0.18 \\
\hline Low risk mortality, n (\%) & $5(63 \%)$ & $0(0 \%)$ & 0.03 \\
\hline In-hospital mortality, n (\%) & $1(13 \%)$ & $2(15 \%)$ & 0.99 \\
\hline
\end{tabular}

Italic values indicate global $\mathrm{p}$ value

$C T$ computed tomography, proBNP pro B-natriuretic peptide, sPESI simplified pulmonary embolismseverity index with COVID-19 may be associated with different mechanisms of thrombotic disease, with more distal process. Coagulopathy and vascular endothelial dysfunction have been proposed to explain the occurrence of PE during COVID-19 outbreak $[3,15]$. This raises the hypothesis of intrapulmonary thrombosis related to COVID-19 during the cytokine storm syndrome [16-21].

Potential limitations of the present study merit consideration. First, we recruited a limited number of patients presenting with PE and COVID-19, leading to non-significant 
Fig. 1 Pulmonary CT angiogpneumonia showing a subsegmental pulmonary thrombus in the right posterior lower pulmonary artery (white arrows) raphy with severe SARS-CoV-2
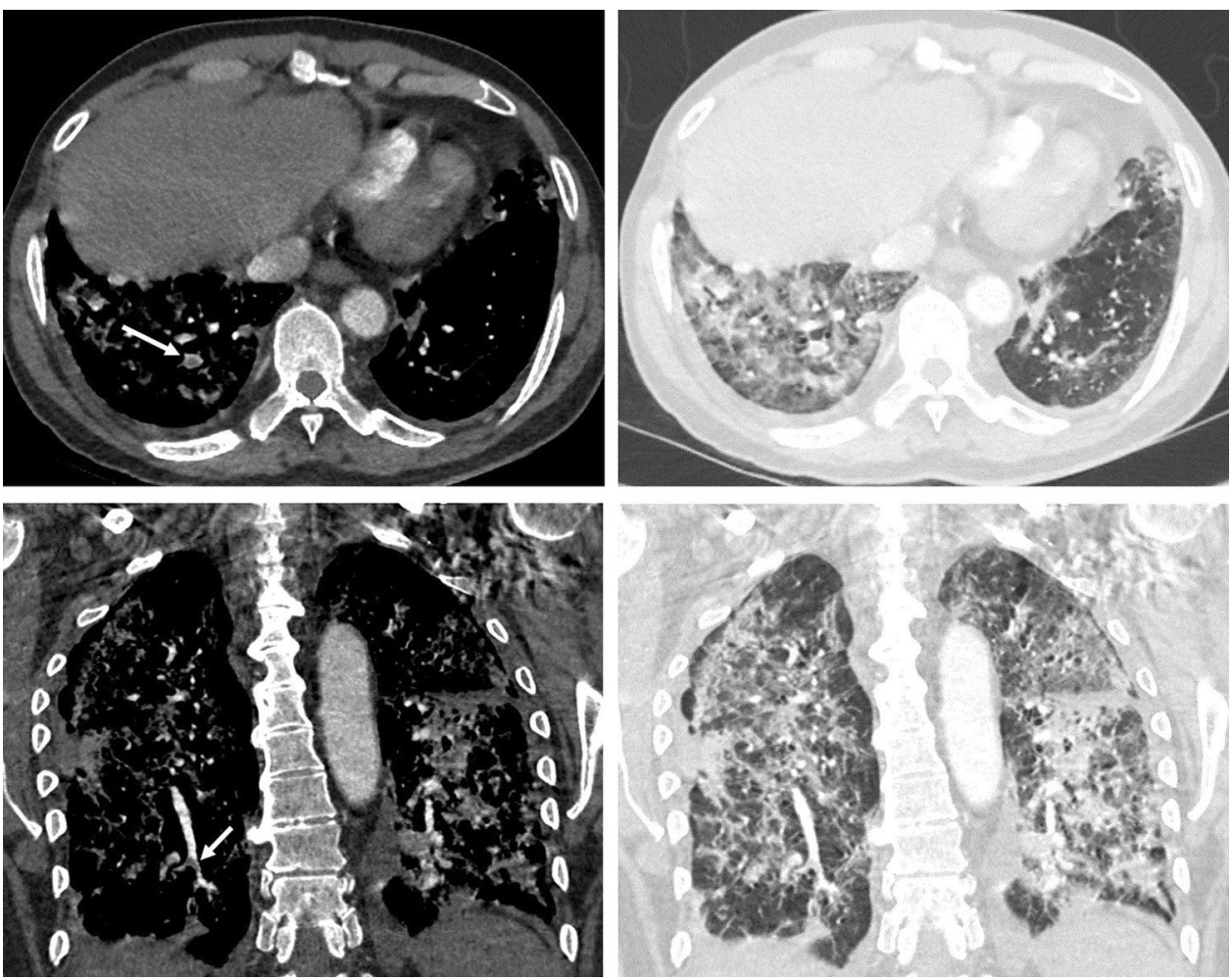

Fig. 2 Number of patients presenting with pulmonary embolism from 2017 to 2020

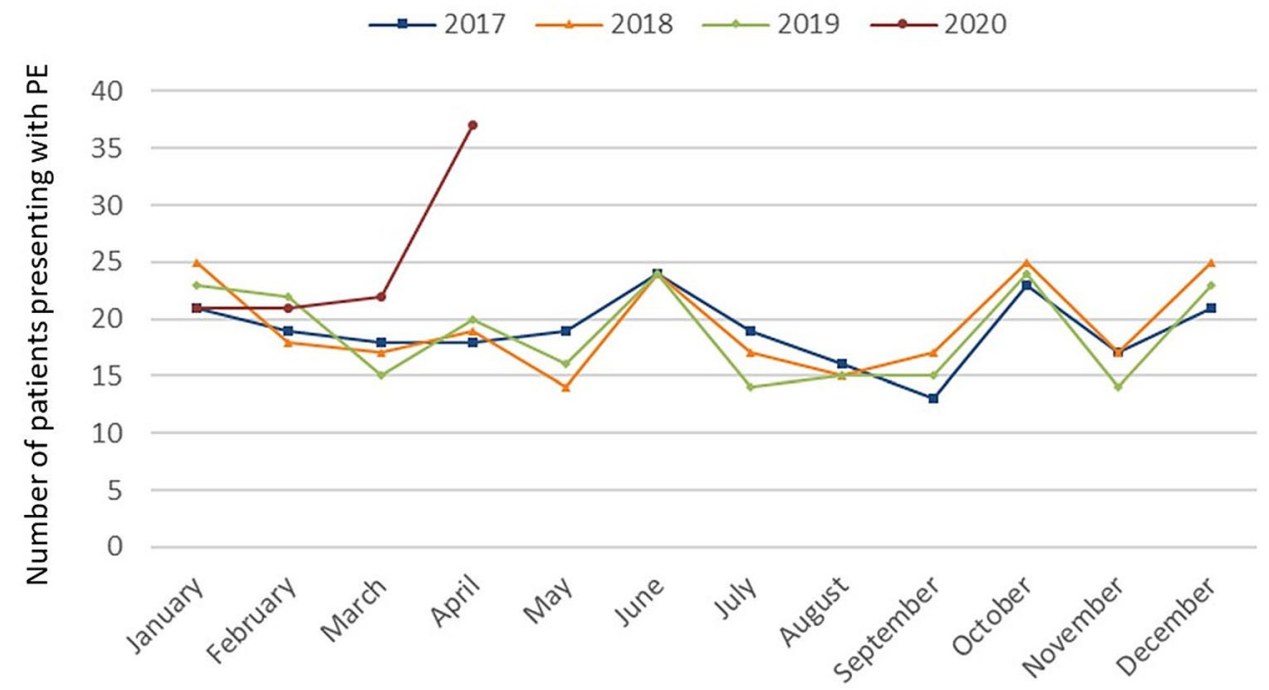

Month differences concerning D-dimer levels $(6273 \pm 3478 \mathrm{ng} /$ $\mathrm{mL}$ in COVID-19 patients versus $4833 \pm 4644 \mathrm{ng} / \mathrm{mL}$ in patients without COVID-19, $p=0.20$ ). Second, during this health crisis, we did not systematically perform venous ultrasonography to assess the occurrence of deep venous thrombosis, to avoid further mobilization of patients. The safety of patients and of health workers led to avoid unnecessary vital examinations. Once the diagnosis of PE was performed, we considered that the diagnosis of thromboembolic disease was made [10]. Finally, since the publication of national guidelines on thromboprophylaxis for hospitalized COVID-19 patients (April 3rd, 2020) [22], a greater awareness of COVID-19-related PE could have an impact on the number of diagnosed PE. However, all of the patients developing PE during hospitalization were receiving a thromboprophylaxic treatment.

In conclusion, the COVID-19 pandemic leads to a dramatic increased incidence in PE admissions. Physicians 
should be aware that PE may be diagnosed at admission, but also after several days of hospitalization, with a different pattern of thrombotic disease.

\section{Compliance with ethical standards}

Conflict of interest The authors declare that they have no conflict of interest.

\section{References}

1. Pneumonia of unknown cause - China: disease outbreak news. Geneva: World Health Organization, January 5, 2020 (https:// www.who.int/csr/don/05-january-2020-pneumonia-of-unkow n-cause-china/en/. opens in new tab).

2. Li Q, Guan X, Wu P, Wang X, Zhou L, Tong Y, Ren R, Leung KSM, Lau EHY, Wong JY, Xing X, Xiang N, Wu Y, Li C, Chen Q, Li D, Liu T, Zhao J, Liu M, Tu W, Chen C, Jin L, Yang R, Wang Q, Zhou S, Wang R, Liu H, Luo Y, Liu Y, Shao G, Li H, Tao Z, Yang Y, Deng Z, Liu B, Ma Z, Zhang Y, Shi G, Lam TTY, Wu JT, Gao GF, Cowling BJ, Yang B, Leung GM, Feng Z (2020) Early transmission dynamics in Wuhan, China, of novel coronavirus-infected pneumonia. N Engl J Med 382:1199-207

3. Zhou F, Yu T, Du R, Fan G, Liu Y, Liu Z, Xiang J, Wang Y, Song B, Gu X, Guan L, Wei Y, Li H, Wu X, Xu J, Tu S, Zhang Y, Chen H, Cao B (2020) Clinical course and risk factors for mortality of adult inpatients with COVID-19 in Wuhan, China: a retrospective cohort study. Lancet 395:1054-1062

4. Poissy J, Goutay J, Caplan M, Parmentier E, Duburcq T, Lassalle F, Jeanpierre E, Rauch A, Labreuche J, Susen S, Lille ICU Haemostasis COVID-19 Group (2020) Pulmonary embolism in COVID-19 patients: awareness of an increased prevalence. Circulation 142:184-186

5. Grillet F, Behr J, Calame P, Aubry S, Delabrousse E (2020) Acute pulmonary embolism associated with COVID-19 pneumonia detected by pulmonary CT angiography. Radiology 23:201544. https://doi.org/10.1148/radiol.2020201544

6. Leonard-Lorant I, Delabranche X, Severac F, Helms J, Pauzet C, Collange O, Schneider F, Labani A, Bilbault P, Moliere S, Leyendecker P, Roy C, Ohana M (2020) Acute pulmonary embolism in COVID-19 patients on CT angiography and relationship to D-Dimer levels. Radiology 23:201561. https://doi.org/10.1148/ radiol.2020201561

7. Llitjos JF, Leclerc M, Chochois C, Monsallier JM, Ramakers M, Auvray M, Merouani K (2020) High incidence of venous thromboembolic events in anticoagulated severe COVID-19 patients. J Thromb Haemost 18:1743-1746

8. Zuckier LS, Moadel RM, Haramati LB, Freeman L (2020) Diagnostic evaluation of pulmonary embolism during the COVID-19 pandemic. J Nucl Med 61:630-631

9. Danzi GB, Loffi M, Galeazzi G, Gherbesi E (2020) Acute pulmonary embolism and COVID-19 pneumonia: a random association? Eur Heart J 41:1858

10. Konstantinides SV, Meyer G, Becattini C, Bueno H, Geersing GJ, Harjola VP, Huisman MV, Humbert M, Jennings CS, Jiménez D, Kucher N, Lang IM, Lankeit M, Lorusso R, Mazzolai L, Meneveau N, Ní Áinle F, Prandoni P, Pruszczyk P, Righini M, Torbicki A, Van Belle E, Zamorano JL, ESC Scientific Document Group
(2019) ESC Guidelines for the diagnosis and management of acute pulmonary embolism developed in collaboration with the European Respiratory Society (ERS). Eur Heart J 2020(41):543-603

11. Chung M, Bernheim A, Mei X, Zhang N, Huang M, Zeng X, Cui J, Xu W, Yang Y, Fayad ZA, Jacobi A, Li K, Li S, Shan H (2020) CT imaging features of 2019 novel coronavirus (2019nCoV). Radiology 295:202-207

12. Li K, Fang Y, Li W, Pan C, Qin P, Zhong Y, Liu X, Huang M, Liao Y, Li S (2020) CT image visual quantitative evaluation and clinical classification of coronavirus disease (COVID-19). Eur Radiol 30:4407-4416

13. Mansencal N, Joseph T, Vieillard-Baron A, Langlois S, El Hajjam M, Qanadli SD, Lacombe P, Jardin F, Dubourg O (2005) Diagnosis of right ventricular dysfunction in acute pulmonary embolism using helical computed tomography. Am J Cardiol 95:1260-3

14. Donze J, Le Gal G, Fine MJ, Roy PM, Sanchez O, Verschuren F, Cornuz J, Meyer G, Perrier A, Righini M, Aujesky D (2008) Prospective validation of the pulmonary embolism severity index. A clinical prognostic model for pulmonary embolism. Thromb Haemost 100:943-948

15. Oxley TJ, Mocco J, Majidi S, Kellner CP, Shoirah H, Singh IP, De Leacy RA, Shigematsu T, Ladner TR, Yaeger KA, Skliut M, Weinberger J, Dangayach NS, Bederson JB, Tuhrim S, Fifi JT (2020) Large-vessel stroke as a presenting feature of Covid-19 in the young. N Engl J Med 382:e60

16. Mehta P, McAuley DF, Brown M, Sanchez E, Tattersall RS, Manson JJ (2020) COVID-19: consider cytokine storm syndromes and immunosuppression. Lancet 395:1033-1034

17. Rizzo P, Vieceli Dalla Sega F, Fortini F, Marracino L, Rapezzi C, Ferrari R (2020) COVID-19 in the heart and the lungs: could we "Notch" the inflammatory storm? Basic Res Cardiol 115:31

18. Pedersen SF, Ho YC (2020) SARS-CoV-2: a storm is raging. J Clin Invest 130:2202-2205

19. McGonagle D, O'Donnell JS, Sharif K, Emery P, Bridgewood C (2020) Immune mechanisms of pulmonary intravascular coagulopathy in COVID-19 pneumonia. Lancet Rheumatol. https://doi. org/10.1016/S2665-9913(20)30121-1

20. Willyard C (2020) Coronavirus blood-clot mystery intensifies. Nature 581(7808):250

21. Fauvel C, Weizman O, Trimaille A, Mika D, Pommier T, Pace N, Douair A, Barbin E, Fraix A, Bouchot O, Benmansour O, Godeau G, Mecheri Y, Lebourdon R, Yvorel C, Massin M, Leblon T, Chabbi C, Cugney E, Benabou L, Aubry M, Chan C, Boufoula I, Barnaud C, Bothorel L, Duceau B, Sutter W, Waldmann V, Bonnet G, Cohen A, Pezel T, Critical Covid-19 France Investigators (2020) Pulmonary embolism in COVID-19 patients: a French multicentre cohort study. Eur Heart J. https://doi.org/10.1093/ eurheartj/ehaa500

22. Susen S, Tacquard CA, Godon A, Mansour A, Garrigue D, Nguyen P, Godier A, Testa S, Albaladejo P, Gruel Y, au nom du GIHP et du GFHT. Traitement anticoagulant pour la prévention du risque thrombotique chez un patient hospitalisé avec COVID-19 et surveillance de l'hémostase. Proposition du GIHP et du GFHT. https://sfar.org/download/traitement-anticoagulant-pour-la-preve ntion-du-risque-thrombotique-chez-un-patient-hospitalise-aveccovid-19-et-surveillance-de-lhemostase/ $\mathrm{wpdmdl}=25834 \&$ refre $\mathrm{sh}=5 \mathrm{fOdaf} 7241 \mathrm{~d} 791594732402$

Publisher's Note Springer Nature remains neutral with regard to jurisdictional claims in published maps and institutional affiliations. 